DR-7

\title{
BIOFILM FOR TREATING BURNS BASED ON THE COMBINATION OF CHEMICAL AND BIOLOGICAL COMPONENTS
}

\author{
A. V.Ageykin, ${ }^{1}$ V. L. Melnikov, ${ }^{1}$ T. N. Dmitrieva, ${ }^{1,2}$ G. V. Vishnevskaya ${ }^{1}$ \\ ${ }^{1}$ Federal State Budgetary Educational Institution of Higher Education "Penza State University", \\ 440029, Russia, Penza, 40 Krasnaya St. \\ ${ }^{2}$ Federal State Budgetary Educational Institution of Higher Education "Penza State University of \\ Architecture and Construction”, 440028, Russia, Penza, 28German Titov St. \\ E-mail: keokushinkai@yandex.ru
}

\begin{abstract}
The problem of treating thermal damage to soft tissues of the body and eliminating skin defects remains one of the most important problems for both theoretical and practical medicine [1]. At this time, the main method of treating thermal skin lesions is early necrectomy with subsequent autodermoplasty [2]. However, when using this method, the mortality rate of seriously ill patients remains high enough, due to the high incidence of infectious complications against the background of prolonged burn wounds, and the impossibility of timely and effective free autodermoplasty [3]. Antibiotics have reduced the number of local and general manifestations, but resistance arises for many of them. Modern developments on the creation of coatings for burn wounds can significantly narrow the indications for the use of antibiotics $[4,5]$. Gradually, other treatment methods based on local use of cultures of allogeneic fibroblasts are being introduced into clinical practice [6, 7]. But these methods are highly costly and inconvenient $[8,9]$. Therefore, there is a need to develop a topical drug that meets all the requirements. Its recipe can be represented as follows: Glycerin - 5.0; Gelatin - 28.5; Trimecaine - 5.0; Purified water $51.5 \mathrm{ml}$; Zinc oxide - 10.0; Tissucol Kit - 5.0
\end{abstract}

\section{References}

1. Hove L.M. Epidemiology of burns in Bergen, Norway. Scand. J. Plast. Reconstr. Surg. Hand. Surg. - 1999. - Vol. 33, No. 2. - P. 226-229.

2. Hakobyan S.R. Early necrectomy with simultaneous skin grafting in treatment of deep burns. Emergency Medical Care. 2006. - Vol. 7, No. 3. - P. 139-140.

3. Petrachkov S.A. Analysis of surgical treatment results for limited burns of IIIb degree. Proceedings of II Congress of Combustiologists of Russia. - Moscow, 2008. - P. 173.

4. Alekseev A.A., Bobrovnikov A.E., Krutikov M.G. Local use of antimicrobial agents for the treatment of burn wounds. Combustiology. 2011. No. 45.

5. Blatun L.A. Local medicamentous treatment of wounds. Pirogov Russian Journal of Surgery. 2011. No. 4. P. 51-59.

6. Budkevich L.I. Ten years of experience using cultured human allofibroblasts in treatment of children with deep burns. Proccedings of XX з'їзду хірургів України. - Тернопіль, 2002. - Vol. 2. - P. 636-639.

7. Matchin E.N., Potapov V.P., Ogoltsova V.A., Kuzko Yu.N. Clinical and histological results of skin autoplasty by traditional methods and using a cell culture of fibroblasts. In: New methods of treating burns using cultured allofibroblasts. International Symposium. Saratov, 1998, p. 25.

8. Dutta R.C., Dutt A.K. Cell interactive 3D-scaffold; advances and applications. Biotechnology Advances. Vol. 27, Issue 4, July-August 2009, Pp. 334-339.

9. Gogolewski S., Pennings A.J. An artificial skin based on biodegradable mixtures of polylactides and polyurethanes for fullthickness skin wound covering. Makromol. Chem. Rapid. Commun. 1983; 4: 675-80. 